\title{
BENTUK PERGESERAN BAHASA JAWA MASYARAKAT SAMIN DALAM RANAH KELUARGA
}

\author{
Hari Bakti Mardikantoro \\ Fakultas Bahasa dan Seni Universitas Negeri Semarang \\ e-mail: haribaktim@yahoo.co.id
}

\begin{abstract}
Abstrak
Penelitian ini bertujuan mendeskripsikan bentuk pergeseran bahasa Jawa yang digunakan oleh masyarakat Samin dalam ranah keluarga. Pengambilan data dilakukan di dua lokasi tempat masyarakat Samin bermukim, yakni Dusun Tambak, Desa Sumber, Kecamatan Kradenan dan Dusun Tanduran, Desa Kemantren, Kecamatan Kedungtuban. Analisis data dilakukan dengan metode etnografi. Hasil penelitian menunjukkan bahwa telah terjadi pergeseran bahasa Jawa yang digunakan oleh masyarakat Samin dari bahasa Jawa ngoko ke bahasa Jawa krama. Bahasa Jawa ngoko yang merupakan ciri khas BJS digunakan dalam berbagai ranah. Namun sejalan dengan berbagai pengaruh, kini masyarakat Samin tidak lagi menggunakan bahasa Jawa ngoko untuk segala keperluan. Bahasa Jawa ngoko hanya digunakan terbatas pada ranah keluarga dan ketetanggaan yang selalu melibatkan sesama masyarakat Samin. Adapun pada ranah yang lain, seperti ranah sosial, pendidikan, dan ranah yang lain, bahasa Jawa ngoko tidak digunakan lagi dan beralih menggunakan bahasa Jawa krama.
\end{abstract}

Kata kunci: pergeseran bahasa, bahasa Jawa ngoko-krama, dan ranah keluarga

\section{FORMS OF THE SHIFT OF JAVANESE IN THE SAMIN COMMUNITY IN THE DOMESTIC DOMAIN}

\begin{abstract}
This study aims to describe the forms of the shift of Javanese in the Samin community in the domestic domain. The data were collected from two locations where the Samin community lives, i.e. Tambak Hamlet, Sumber Village, Kradenan District and Tanduran Hamlet, Kemantren Village, Kedungtuban District. The data were ethnographically analyzed. The findings show that there is a shift of Javanese in the Samin community from the ngoko Javanese to the krama Javanese. The ngoko language, which is the characteristic of Javanese in the Samin community, is used in a variety of domains. However, due to a variety of causes, the Samin community does not use the ngoko Javanese for all purposes. It is used only in the domestic domain and neighborhood involving the members of the Samin community only. In other domains such as social and educational domains, the ngoko Javanese is not used anymore and there is a shift to the krama Javanese.
\end{abstract}

Keywords: language shift, ngoko-krama Javanese, domestic domain

\section{PENDAHULUAN}

Bahasa yang dimiliki oleh suatu masyarakat tutur dalam khazanah bahasanya selalu memiliki variasi. Hal itu disebabkan oleh kenyataan bahwa bahasa yang hidup dalam masyarakat selalu digunakan dalam peran-peran sosial para penuturnya. Peran-peran sosial itu berkaitan dengan berbagai aspek sosial psikologis yang kemudian dirinci 
dalam bentuk komponen-komponen tutur (Poedjosoedarmo, 1982:3). Adanya fenomena pemakaian variasi bahasa dalam masyarakat tutur dikontrol oleh faktor-faktor sosial, budaya, dan situasional (Kartomihardjo, 1981; Fasold, 1984; Hudson, 1996).

Dalam bahasa Jawa yang digunakan oleh masyarakat Samin (selanjutnya disingkat BJS) dapat dijelaskan fenomena hubungan antara bahasa dan faktor sosial budaya masyarakat penuturnya. BJS sangat kental dengan budaya masyarakat Samin. Dalam beberapa hal penggunaannya, BJS agak berbeda dengan bahasa Jawa pada umumnya karena kehidupan sosial budaya masyarakat Samin dalam beberapa hal juga berbeda dengan kehidupan sosial budaya masyarakat Jawa pada umumnya.

Pada mulanya masyarakat Samin dalam berkomunikasi selalu menggunakan bahasa Jawa ngoko, yakni bahasa Jawa yang sederhana atau bersahaja. Oleh karena itu, orang Samin sering disebut "orang Jawa lugu" atau "Jawa Jawab", artinya orang Jawa yang selalu berbicara dengan lugu (Widodo, 1997:276). Mereka tidak mau mempelajari dan menggunakan bahasa lain. Menurut pemikiran mereka, orang Jawa itu harus berbahasa Jawa dan tidak pantas menggunakan bahasa asing. Dalam pikiran mereka, orang asing (Belanda) suka menjajah dan merampas kemerdekaan manusia. Oleh karena itu, mereka tidak suka dengan orang asing dan akibatnya mereka tidak mau menggunakan bahasa selain bahasa Jawa (Mumfangati dkk, 2004:36).

Sejalan dengan perkembangan zaman dan berbagai pengaruh, baik pengaruh ilmu pengetahuan dan teknologi maupun sosial budaya, telah terjadi perubahan penggunaan bahasa. Saat ini masyarakat Samin sudah mengenal tingkat tutur bahasa Jawa, meskipun tidak seperti masyarakat Jawa pada umumnya yang menggunakan tingkat bahasa Jawa secara kompleks, seperti bahasa Jawa krama, madya, dan ngoko. Dengan demikian, diasumsikan telah terjadi pergeseran bahasa Jawa yang digunakan oleh masyarakat Samin.

Penelitian ini merupakan kajian sosiolinguistik yang bertumpu pada fenomena bahasa dalam hubungannya dengan masyarakat pemakainya (Wardaugh, 1986:12; Holmes, 1992:1; dan Hudson, 1996:1). Keberagaman bahasa dalam masyarakat yang dwibahasa atau multibahasa dapat memunculkan adanya kontak bahasa ataupun kontak dialek dalam masyarakat tuturnya. Kontak bahasa dan kontak dialek dalam konteks masyarakat multikultural berbagai wilayah dialek di Jawa secara sosiolinguistik berpotensi menimbulkan gejala pergeseran bahasa. Pergeseran bahasa berawal dari penyusutan fungsi-fungsi dasarnya yang umumnya terjadi dalam rentang waktu yang lama dan perlahan-lahan, melampaui berapa generasi (Mbete, 2003:14).

Pergeseran bahasa yang dimaksud dalam penelitian ini adalah pergeseran kode bahasa Jawa yang digunakan oleh masyarakat Samin dari bahasa Jawa ragam ngoko ke bahasa Jawa ragam krama. Pergeseran bahasa tersebut tentu terkait dengan perubahan sosial budaya yang terjadi pada masyarakat Samin sendiri.

Pergeseran bahasa Jawa pada masyarakat Samin ini menarik untuk diteliti karena kajian ini tidak saja bertemali dengan aspek kebahasaan, melainkan juga dengan aspek sosial budaya. Oleh karena itu, penelitian ini dirancang tidak saja memotret segi kebahasaannya saja, tetapi juga mengungkap faktor sosial budaya yang melatarbelakangi pergeseran bahasa yang digunakan masyarakat Samin tersebut. Tulisan ini hanya memaparkan temuan yang berupa bentuk pergeseran bahasa Jawa masyarakat Samin dalam ranah keluarga.

Ada beberapa teori yang digunakan sebagai landasan dalam penelitian ini. Teori yang dimaksud adalah teori sosiolinguistik, variasi bahasa, dan pergeseran 
serta pemertahanan bahasa. Sosiolinguistik mengkaji hubungan antara bahasa dan masyarakat yang mengaitkan dua bidang yang dapat dikaji secara terpisah, yakni struktur formal bahasa oleh linguistik dan struktur masyarakat oleh sosiologi (Wardhaugh, 1986:4 dan Holmes, 1992:1). Bahasa dalam kajian sosiolinguistik tidak didekati sebagai bahasa dalam kajian linguistik teoretis, melainkan didekati sebagai sarana interaksi dalam masyarakat.

Sejalan dengan pernyataan tersebut, Kartomihardjo (1981:4) mengemukakan gagasan tentang objek kajian sosiolinguistik. Menurutnya sosiolinguistik mengkaji hubungan antara pembicara dan pendengar, berbagai macam bahasa dan variasinya, pengunaan sesuai dengan berbagai faktor penentu baik faktor kebahasaan maupun lainnya, serta bebagai bentuk bahasa yang hidup dan dipertahankan di dalam suatu masyarakat. Gagasan ini dapat ditafsirkan bahwa pengertian sosiolinguistik mencakupi bidang kajian yang luas, tidak hanya menyangkut wujud formal bahasa dan variasi bahasa, melainkan juga menyangkut penggunaan bahasa di masyarakat. Penggunaan bahasa tersebut berkaitan dengan berbagai faktor, baik faktor kebahasaan maupun faktor nonkebahasaan, seperti faktor sosial budaya.

Bahasa yang dimiliki oleh satu masyarakat tutur dalam khasanah bahasanya selalu memiliki variasi. Alasannya yaitu bahasa yang hidup dalam masyarakat selalu digunakan dalam peran-peran sosial tempat penggunaan bahasa atau variasi bahasa itu. Peranperan sosial itu berkaitan dengan berbagai aspek sosial psikologis yang kemudian dirinci dalam bentuk komponen-komponen tutur. Dalam kajian pemilihan bahasa, tugas sosiolinguistik adalah berusaha mendeskripsikan hubungan antara gejala pemilihan bahasa dan faktor-faktor sosial, budaya, dan situasional dalam masyarakat dwibahasa atau multibahasa, baik secara korelasional maupun implikasional.
Salah satu kajian sosiolinguistik adalah hubungan bahasa dengan etnis. Hubungan ini telah lama menjadi perbincangan yang cukup menarik perhatian para ahli linguistik khususunya bidang sosiolinguistik. Thomason (2001:22) menyatakan bahwa dewasa ini penelitian banyak difokuskan pada konsep etnisitas dan implikasinya bagi pemertahanan dan pergeseran bahasa. Isu besarnya adalah masalah bahasa sebagai simbol etnisitas dan loyalitas bahasa yang pada akhirnya sampai pada masalah sikap menusia terhadap bahasanya. Oleh karena berhubungan dengan sikap inilah, masalah tersebut menjadi masalah yang sulit diprediksi dengan pasti.

Dalam kepustakaan sosiolinguistik, pemertahanan dan pergeseran bahasa merupakan fenomena yang menarik. Terminologi pemertahanan dan pergeseran bahasa pertama kali diperkenalkan oleh Fishman pada tahun 1964. Beberapa penelitian tentang pergeseran bahasa pernah dilakukan oleh Errington (1998) dan Smith-Hefner (2009). Pemertahanan dan pergeseran bahasa erat kaitannya dengan ranah yang berkaitan dengan pilihan bahasa dan kedwibahasaan (Rokhman, 2009:3)

Dalam kenyataan berbahasa, bahasa dapat menggeser bahasa lain atau bahasa yang tidak tergeser oleh bahasa lain. Bahasa yang tergeser adalah bahasa yang tidak mampu mempertahankan diri (Sumarsono dan Partana, 2002:231). Kedua kondisi ini merupakan akibat dari pilihan bahasa dalam jangka panjang (paling tidak tiga generasi) dan bersifat kolektif (dilakukan oleh seluruh warga guyub). Hal ini juga disampaikan oleh Fasold (1984: 213-214) bahwa pergeseran dan pemertahanan bahasa merupakan hasil dari proses pemilihan bahasa dalam jangka waktu yang sangat panjang. Pergeseran bahasa menunjukkan adanya suatu bahasa yang benar-benar ditinggalkan oleh komunitas penuturnya. 
Berbicara mengenai pergeseran dan pemertahanan suatu bahasa, ada fakta tidak terbantahkan, yakni ada bahasa yang masih setia digunakan oleh penuturnya dalam semua lapisan usia dan digunakan dalam berbagai ranah pertuturan. Ada bahasa yang hanya digunakan oleh selapis generasi tua dan telah ditinggalkan oleh anak-anak dan remaja. Ada pula bahasa yang hanya digunakan oleh beberapa orang tua dan sebagian besar penutur tidak lagi cakap menggunakannya. Dari sudut pandang daya hidupnya, bahasa tipe pertama adalah bahasa yang diprediksi masih panjang usia hidupnya, sedangkan bahasa tipe kedua dan ketiga dalam kurun waktu tidak terlalu lama akan mengalami kepunahan (Ibrahim, 2011:36).

Pergeseran bahasa berarti suatu guyub atau komunitas meninggalkan suatu bahasa sepenuhnya untuk memakai bahasa lain (Sumarsono dan Partana, 2002:231). Apabila pergeseran sudah terjadi, para warga guyub itu secara kolektif memilih bahasa baru. Dalam pemertahanan bahasa, guyub itu secara kolektif menentukan untuk melanjutkan memakai bahasa yang sudah biasa dipakai. Ketika guyub tutur mulai memilih bahasa baru dalam ranah yang semula diperuntukkan bagi bahasa lama, itulah mungkin merupakan tanda bahwa pergeseran sedang berlangsung. Jika para warga itu monolingual dan secara kolektif tidak menghendaki bahasa lain, mereka jelas mempertahankan pola penggunaan bahasa mereka. Namun pemertahanan bahasa itu sering merupakan ciri guyub dwibahasa atau ekabahasa. Yang pertama akan terjadi jika guyub itu diglosik. Guyub itu memperuntukkan ranah tertentu untuk setiap bahasa sedemikian rupa sehingga batas ranah suatu bahasa tidak melampaui atau diterobos oleh bahasa lain.

Pergeseran bahasa berkaitan erat dengan masalah penggunaan bahasa oleh seorang penutur atau sekelompok penutur yang bisa terjadi sebagai akibat per- pindahan dari satu masyarakat tutur ke masyarakat tutur yang lain. Apabila seorang atau sekelompok penutur pindah ke tempat lain yang menggunakan bahasa yang berbeda dan bercampur dengan kelompok baru dan dengan bahasa yang baru pula, maka akan terjadilah pergeseran bahasa ini. Bagi kelompok pendatang untuk keperluan berkomunikasi mau tidak mau harus menyesuaikan diri dengan menggunakan bahasa penduduk setempat dan menanggalkan bahasanya sendiri.

Para penutur yang lebih tua akan menggunakan bahasa tradisional dalam banyak situasi dan para penutur yang lebih muda akan lebih banyak menggunakan bahasa baru dalam banyak domain. Akan tetapi, pola seperti ini harus diinterpretasikan dengan cermat. Ada beberapa karakteristik dalam pergeseran suatu bahasa. Pertama mungkin akan muncul pola 'deviasi' yang menunjukkan model yang bertentangan. Kedua, distribusi usia bisa jadi bukan merupakan gejala perubahan, tetapi lebih merefleksikan perubahan dalam penggunaan bahasa seseorang dari suatu periode ke periode lain

Tahap selanjutnya dari pergeseran bahasa juga dapat dilihat dari beberapa karakteristik. Pertama, bahasa tradisional yang tergantikan oleh bahasa baru dalam pergeseran bahasa dianggap inferior. Selain itu, akan ada pula ketidakseimbangan peminjaman kata. Kata-kata dari bahasa baru dengan bebas akan dipinjam oleh bahasa tradisional, tetapi tidak sebaliknya. Tentu saja tahap akhir pergeseran bahasa terjadi ketika para orang tua yang bilingual dalam suatu komunitas bahasa hanya mengajarkan bahasa baru pada anak-anaknya.

Gejala-gejala yang menunjukkan terjadinya pergeseran dan pemertahan bahasa pun dapat diamati. Misalnya, ketika ada gejala yang menunjukkan bahwa penutur suatu komunitas bahasa mulai memilih menggunakan bahasa baru dalam domain-domain tertentu yang 
menggantikan bahasa lama, hal ini memberikan sinyal bahwa proses pergeseran bahasa sedang berlangsung. Akan tetapi, apabila komunitas penutur bahasanya monolingual dan secara kolektif tidak menggunakan bahasa lain, maka dengan jelas ini berarti bahwa komunitas bahasa tersebut mempertahankan pola penggunaan bahasanya. Pemertahanan bahasa bukan hanya terjadi di dalam komunitas tutur yang monolingual, tetapi terjadi pula dalam masyarakat bilingualisme serta multilingualisme. Namun, hal semacam ini hanya terjadi ketika komunitas penutur bahasanya diglosia.

Artikel ini membicarakan pergeseran kode bahasa pada masyarakat Samin di Kabupaten Blora dari penggunaan bahasa Jawa ngoko ke bahasa Jawa krama, khususnya dalam ranah keluarga. Pada awalnya, masyarakat Samin dikenal sebagai masyarakat yang hanya bisa berbahasa Jawa ngoko. Namun seiring dengan keterbukaan mereka, kini masyarakat Samin sudah bisa menggunakan bahasa Jawa krama.

\section{METODE}

Data dalam penelitian ini dijaring dengan menggunakan metode simak. Sehubungan dengan itu, peneliti selalu mengamati setiap penggunaan bahasa. Pengamatan itu, secara khusus, dilaksanakan dengan menerapkan teknik sadap sebagai teknik dasarnya dan diteruskan dengan teknik lanjutan yang berupa teknik simak libat cakap, tekik simak bebas libat cakap, teknik rekam, dan teknik catat. Teknik-teknik tersebut digunakan secara komprehensif untuk memperoleh data yang bervariasi. Dalam teknik simak libat cakap, peneliti berpartisipasi dalam pembicaraan dan menyimak pembicaraan (Sudaryanto, 1993: 133). Dengan demikian, peneliti terlibat langsung dalam dialog. Sementara itu, teknik simak bebas libat cakap digunakan karena peneliti tidak terlibat dalam dialog, konversi, atau imbal wicara. Jadi, peneliti tidak ikut serta dalam proses pembicaraan orang-orang yang saling berbicara (Sudaryanto, 1993: 134). Dengan demikian, dapat dikatakan bahwa penjaringan data dilakukan dengan metode observasi-partisipatif. Di samping itu, supaya proses pengumpulan data dapat berlangsung dengan baik, peneliti juga menggunakan bantuan tape recorder.

Kajian BJS difokuskan pada bahasa Jawa yang digunakan oleh masyarakat Samin di Kabupaten Blora. Masyarakat Samin di Kabupaten Blora tersebar di beberapa desa. Oleh karena itu, pengambilan data akan difokuskan di dua lokasi tempat masyarakat Samin bermukim. Dua lokasi tersebut adalah Dusun Tambak, Desa Sumber, Kecamatan Kradenan dan Dusun Tanduran, Desa Kemantren, Kecamatan Kedungtuban. Pemilihan lokasi ini didasarkan atas pertimbangan bahwa kedua desa tersebut merupakan daerah yang penduduknya sebagian besar adalah orang-orang Samin. Masyarakat Samin di dua lokasi tersebut masih hidup berkelompok dan sampai saat ini tetap melaksanakan adat dan kebiasaan orang Samin.

Analisis data dalam penelitian etnografi lazimnya dilakukan melalui dua prosedur, yaitu (1) analisis selama proses pengumpulan data dan (2) analisis setelah pengumpulan data (Miles dan Huberman, 1984:21-25 dan Muhadjir, 1996:105). Prosedur pertama dilakukan dengan langkah (a) reduksi data (data reduction), yaitu melakukan identifikasi pemakaian bahasa Jawa masyarakat Samin; (b) sajian data dengan matrik; dan (c) pengambilan simpulan/verifikasi yang sifatnya tentatif, baik dengan trianggulasi data maupun dengan trianggulasi teknik pengambilan data.

Prosedur kedua dilakukan dengan langkah (a) transkripsi fonetis data hasil rekaman, (b) pengelompokan atau klasifikasi data dari rekaman dan pencatatan berdasarkan tataran kebahasaan dan faktor sosial budaya, (c) penafsiran perbe- 
daan pemakaian bahasa BJS berdasarkan faktor sosial budaya, (d) penyimpulan atau perampatan tentang pemakaian bahasa Jawa masyarakat Samin. Untuk menjaga kredibilitas data ditempuh langkah (i) diskusi dengan teman sejawat dan dosen pembimbing dan (ii) pengecekan ulang pada informan.

\section{HASIL DAN PEMBAHASAN}

Pada bagian ini akan dibahas pergeseran bahasa Jawa yang digunakan oleh masyarakat Samin di Kabupaten Blora. Pergeseran tersebut tampak dari bergesernya fungsi BJS dan berkurangnya penggunaan BJS dalam berbagai ranah. Di samping itu, akan dijelaskan pula bentuk pergeseran BJS dalam ranah keluarga.

\section{Pergeseran Bahasa Jawa Masyarakat Samin}

Kajian pergeseran bahasa perlu dikaitkan dengan konsep pemilihan bahasa. Pemahaman tentang pilihan bahasa dalam ranah yang dihubungkan dengan konsep diglosia sangat penting artinya karena dengan begitu pemertahanan dan kebocoran diglosia yang menyebabkan pergeseran bahasa dapat dilihat. Pergeseran bahasa serta kepunahan suatu bahasa bertitik tolak dari kontak dua bahasa dalam suatu masyarakat. Gejala kepunahan bahasa akan tampak dalam proses yang cukup panjang. Mula-mula tiap-tiap bahasa masih dapat mempertahankan pemakaiannya pada ranah masing-masing. Kemudian pada suatu masa transisi masyarakat tersebut menjadi dwibahasawan sebagai suatu tahapan sebelum kepunahan bahasa aslinya (B1) dan dalam jangka waktu beberapa generasi mereka bertransformasi menjadi masyarakat ekabahasawan kembali. Dengan demikian, pergeseran bahasa mencakup pertamapertama kedwibahasaan (seringkali bersama diglosia) sebagai suatu tahapan menuju keekabahasaan (B1 yang baru) (Rokhman, 2009:3). Di samping itu, gejala pergeseran bahasa sering dikaitkan de- ngan semakin berkurangnya ranah penggunaan bahasa (Grimes, 2000:64). Hal ini bisa dipahami karena ranah penggunaan bahasa memperlihatkan seberapa luas bahasa tersebut dipakai dan dipertahankan oleh para penuturnya.

Saat ini BJS juga sudah mengalami pergeseran. Pergeseran BJS yang dimaksud dalam penelitian ini adalah pergeseran penggunaan bahasa Jawa dari tingkat ngoko ke bahasa Jawa tingkat krama. Dalam penggunaannya, BJS yang mempunyai ciri khas tidak mengenal tingkat krama sudah sangat terbatas penggunaannya. Saat ini, masyarakat Samin sudah mulai mengenal dan menggunakan bahasa Jawa krama dalam berbagai kesempatan tuturan, apalagi jika tuturan itu dilakukan dengan orang non-Samin. Bahkan tuturan yang dilakukan antarsesama masyarakat Samin pun sekarang sudah menggunakan bahasa Jawa krama.

Tuturan antarsesama masyarakat Samin yang sering menggunakan bahasa Jawa krama adalah tuturan antara masyarakat Samin generasi muda dengan masyarakat Samin generasi tua. Mereka sudah menyadari menggunakan bahasa Jawa krama merupakan salah satu bentuk penghormatan kepada orang tua, walaupun masyarakat Samin sendiri mempunyai anggapan bahwa yang paling penting adalah perilakunya bukan dari bahasa yang digunakan. Namun demikian, masyarakat Samin menyadari perilaku yang baik jika ditunjang dengan penggunaan bahasa yang santun akan menambah lengkap perilaku mereka.

Bergesernya pengguaan bahasa Jawa oleh masyarakat Samin juga diakui oleh Kamituwa Dusun Tambak yang sebagain warganya merupakan masyarakat Samin. Berdasarkan hasil wawancara dengan peneliti, Bapak Sugiyanto (Kamituwa Dusun Tambak, Desa Sumber, Kecamatan Kradenan) menyatakan bahwa bahasa yang digunakan untuk berkomunikasi oleh masyarakat Samin di Dusun Tambak adalah bahasa Jawa. Bahasa Jawa yang 
digunakan sudah seperti bahasa Jawa yang digunakan oleh masyarakat Jawa lainnya yakni bahasa Jawa yang sudah mengenal tingkat tutur krama. Hal yang sama dikatakan Kepala Desa Sumber, Bapak Sunoto. Beliau juga mengatakan hal yang sama seperti yang disampaikan Bapak Sugiyanto, yakni masyarakat Samin dalam berbahasa sudah tidak seperti dulu lagi yang selalu menggunakan bahasa Jawa ngoko ketika berkomunikasi dengan siapa pun. Sekarang masyarakat Samin sudah menggunakan bahasa Jawa krama terutama ketika berbicara dengan orang non-Samin maupun orang yang dihormati.

Seperti yang sudah diurai pada bagian terdahulu, Grimes (2000:64) memperkirakan salah satu penyebab gejala pergeseran dan kepunahan bahasa adalah semakin berkurangnya ranah penggunaan bahasa. Gejala tersebut juga dapat dipakai untuk menjelaskan pergeseran bahasa Jawa pada masyarakat Samin.

Salah satu fungsi bahasa Jawa bagi masyarakat Samin adalah sebagai pengungkap isi, pengungkap pengalaman penutur tentang dunia nyata, termasuk dunia dalam kesadarannya sendiri. Dalam hal ini, BJS digunakan untuk mengungkapkan pikiran dan perasaan masyarakat Samin kepada orang lain. Dengan demikian, BJS tidak bisa dipisahkan dengan masyarakat Samin sendiri yang mempunyai latar belakang budaya yang unik. BJS yang unik merupakan bukti perilaku masyarakat Samin yang unik dan sekaligus cara berpikirnya. Sesuai dengan fungsi tersebut, penggunaan bahasa oleh masyarakat Samin mencakupi berbagai ranah karena masyarakat Samin di samping sebagai makhluk individu juga merupakan makhluk sosial, sehingga membutuhkan komunikasi dengan sesamanya. Bahasa Jawa ngoko yang merupakan ciri khas BJS digunakan dalam berbagai ranah. Namun sejalan dengan berbagai pengaruh, kini masyarakat Samin tidak lagi menggunakan bahasa Jawa ngoko un- tuk segala keperluan. Bahasa Jawa ngoko hanya digunakan terbatas pada ranah keluarga dan ketetanggaan yang selalu melibatkan sesama masyarakat Samin. Adapun pada ranah yang lain, seperti ranah sosial, pendidikan, dan ranah yang lain, bahasa Jawa ngoko tidak digunakan lagi. Bahasa yang digunakan adalah bahasa Jawa dengan mempertimbangkan tingkat tutur sesuai dengan mitra tutur yang dihadapi. Dengan demikian, dalam berkomunikasi masyarakat Samin sudah mengenal dan mempertimbangkan mitra tuturnya. Dalam ranah keluarga dan ketetanggaan pun, masyarakat Samin tidak selalu menggunakan bahasa Jawa ngoko, tetapi juga sudah mempertimbangkan dengan siapa berbicara (B2).

Di samping berkurangnya ranah penggunaan bahasa, fungsi penggunaan bahasa Jawa ngoko pun juga sudah mengalami pergeseran. Berdasarkan sejarahnya, bahasa Jawa ngoko oleh masyarakat Samin dipakai sebagai bentuk melawan penjajah Belanda seperti yang disampaikan oleh Hutomo (1996:35) bahwa pada masa sekitar tahun 1900, mandor hutan yang menjadi antek Belanda mulai menerapkan pembatasan bagi masyarakat dalam soal pemanfaatan hutan. Para mandor itu berbicara soal hukum, peraturan, serta hukuman bagi yang melanggar. Namun para pengikut Samin menganggap remeh perkara itu. Sosialisasi hukum itu lantas ditindaklanjuti pemerintah Belanda dengan pemungutan pajak untuk air, tanah, dan usaha ternak mereka. Pengambilan kayu dari hutan harus seizin mandor polisi hutan. Pemerintah Belanda berdalih semua pajak itu kelak dipakai untuk meningkatkan kesejahteraan rakyat. Akal bulus itu ditentang oleh masyarakat pinggir hutan di bawah komando Samin Surosentiko yang diangkat oleh pengikutnya sebagai pemimpin informal. Para pengikut Samin berpendapat, langkah swastanisasi kehutanan tahun 1875 yang mengambil alih tanah-tanah kerajaan menyengsarakan masyarakat dan membuat 
mereka terusir dari tanah leluhurnya. Sebelumnya, pemahaman pengikut Samin adalah tanah dan udara adalah hak milik komunal yang merupakan perwujudan kekuasaan Tuhan Yang Maha Esa. Mereka menolak berbicara dengan mandormandor hutan dan para pengelola dengan bahasa Jawa krama. Sebagai gantinya para pengikut Samin memperjuangkan hakhaknya dalam satu bingkai, menggunakan bahasa yang sama, Jawa ngoko yang kasar alias tidak taklim. Sasaran mereka sangat jelas, para mandor hutan dan pejabat pemerintah Belanda. Ketika mandor hutan menarik pajak tanah, secara demonstratif mereka berbaring di tengah tanah pekarangannya sambil berteriak keras, "Kanggo!" 'punya saya'. Ini membuat para penguasa dan orang-orang kota menjadi sinis dan mengkonotasikan pergerakan tersebut sebagai sekadar perkumpulan orang tidak santun. Penguasa bahkan mendramatisasikan dengan menyatakan "Wong ora bisa basa" atau dianggap tak beradab. Akibatnya, para pengikut Samin yang kemudian disebut orang Samin, dicemooh dan dikucilkan dari pergaulan.

Kini penjajah Belanda sudah pergi dan Indonesia sudah merdeka, bahkan tahun 2011 ini rakyat Indonesia memperingati kemerdekaan Republik Indonesia ke-66. Tidak ada lagi bentuk perlawanan masyarakat Samin. Bahkan masyarakat Samin sangat taat aturan dan selalu mengikuti keumuman masyarakat lainnya. Mereka sangat supel dan selalu mengikuti kegiatan masyarakat lainnya atau kegiatan yang telah ditentukan pemerintah desa. Di samping itu, masyarakat Samin juga terkenal sebagai pembayar pajak yang taat (hasil wawancara dengan Bapak Sunoto, Kepala Desa Sumber Kecamatan Kradenan, Kabupaten Blora.

\section{Bentuk Pergeseran Bahasa Jawa Masya- rakat Samin dalam Ranah Keluarga}

Pada mulanya, masyarakat Samin dalam berkomunikasi selalu menggunakan bahasa Jawa ngoko. Masyarakat Samin tidak mengenal tingkat bahasa Jawa, seperti bahasa Jawa krama, madya, dan ngoko (Hutomo, 1996:35; Mumfangati dkk, 2004:36). Dalam ajaran Samin siapapun sama. Mereka tidak pernah membedabedakan orang. Manusia hidup mempunyai kedudukan dan tingkatan yang sama. Oleh karena itu, dalam pergaulan sehari-hari, terutama dengan sesama sedulur, orang Samin menggunakan bahasa Jawa ngoko.

Namun sejalan dengan perkembangan zaman dan berbagai pengaruh, baik pengaruhilmu pengetahuan dan teknologi maupun sosial budaya telah terjadi perubahan penggunaan bahasa. Saat ini masyarakat Samin sudah mengenal tingkat tutur bahasa Jawa, meskipun tidak seperti masyarakat Jawa pada umumnya yang menggunakan tingkat tutur bahasa Jawa secara kompleks. Dengan demikian, diasumsikan telah terjadi pergeseran bahasa Jawa yang digunakan oleh masyarakat Samin. Pergeseran yang dimaksud di sini adalah pergeseran kode bahasa, yakni pergeseran dari bahasa Jawa ngoko ke bahasa Jawa krama.

Masyarakat Samin merupakan masyarakat yang hidupnya mengelompok dalam suatu wilayah. Dengan demikian, hubungan antara keluarga yang satu dengan keluarga yang lain sangat erat. Bahkan di antara mereka banyak yang masih mempunyai hubungan kekerabatan. Dalam masyarakat Samin, keluarga merupakan basis kelompok. Hubungan antaranggota keluarga sangat erat. Keluarga dalam masyarakat Samin bisaanya beranggotakan Mak 'bapak', Yung 'ibu', dan turune 'anak-anak'. Seorang anak yang sudah menikah biasaanya akan membentuk keluarga baru dan tinggal di rumah yang berbeda meskipun masih dalam lingkungan yang sama.

Masyarakat Samin setelah pulang dari bertani di sawah selalu berada di rumah berkumpul dengan keluarga dan sesekali bertandang ke rumah tetangga. Tidak ada acara yang dilakukan setelah pulang dari 
sawah. Dengan kondisi ini, masyarakat Samin memang lebih banyak berada di rumah setelah bekerja. Mereka bisaanya berkumpul pada satu ruangan dengan anggota keluarga lain. Dalam kesempatan seperti ini, para anggota keluarga akan selalu berbincang mengenai persoalan sehari-hari. Mereka berkomunikasi menggunakan bahasa Jawa. Di sinilah terjadi pergeseran penggunaan bahasa Jawa. Data yang bisa diamati :

(1) P1 : Siman, apa wis nduwe KTP?

[Siman, OpO wIs nduwe KTP?]

'Siman, apa sudah punya KTP?'

P2 : Alah ya nduwe ae

[Alah yT nduwe ae.]

'Alah, ya punya saja'

P3 : Mpun dibeta kawit lair nggih, KTP wujude nggih niki leh

[MpUn dibYtO kawIt laIr KgIh, KTP wujude KgIh niki låh]

'Sudah dibawa sejak lahir, wujudnya ya ini'

P2 : Ya gambar iki, karik sing nggambar, ning jare KTP ki sing digambar rak ya wong leh, ning wujude ya ngono $i k i$

[yO gambar iki, karI? sIK Kgambar, nIK jare KTP ki sIK digambar $\mathrm{ra}$ ? yO wOK låh, nIK wujude $\mathrm{yT}$ ngono iki]

'Ya gambar ini, tinggal yang menggembar, tetapi katanya KTP yang digambar ya orang, tetapi wujudnya ya seperti ini'

Tuturan pada data (1) terjadi pada sebuah keluarga yang merupakan warga Samin. Tuturan tersebut terjadi dalam situasi nonformal antara seorang ibu (P1), ayah (P2), dan anak menantunya (P3). Topik yang dibicarakan adalah topik sehari-hari, yakni tentang KTP (Kartu Tanda Penduduk). Topik ini muncul dalam pembicaraan karena kebetulan dalam keluarga itu ada pak Kamituwa yang sedang menguruskan KTP salah satu warga Samin. Namun pembicaraan dalam data (1) terjadi antara seorang ayah, ibu, dan anak menantunya dalam sebuah keluarga, sehingga dapat dikategorikan dalam ranah keluarga. P1 mengawali pembicaraan dengan menggunakan bahasa Jawa ngoko menanyakan tetangganya bernama Siman apakah sudah mempunyai KTP. P2 merespon pertanyaan P1 juga menggunakan bahasa Jawa ngoko. Akan tetapi, P3 yang ikut dalam pembicaraan antara P1 dan P2 merespons pembicaraan itu dengan menggunakan bahasa Jawa krama. Tuturan mpun dibeta kawit lair nggih, KTP wujude nggih niki leh merupakan tuturan yang diucapkan oleh P3 dalam bahasa Jawa krama.

Dalam konteks pembicaraan seperti itu telah terjadi pergeseran (kode) bahasa dari bahasa Jawa ragam ngoko ke bahasa Jawa ragam krama yang dituturkan oleh P1. Dalam masyarakat Samin, komunikasi dalam keluarga dahulu dilakukan dalam bahasa ngoko, baik antara ayah, ibu, dan anak maupun sebaliknya. Dalam pembicaraan antara anak dengan orang tuanya, masyarakat Samin juga cenderung menggunakan bahasa Jawa ngoko termasuk kata-kata yang mestinya diungkapkan dengan bahasa Jawa ragam krama. Dengan demikian, tuturan Mpun dibeta kawit lair nggih, KTP wujude nggih niki leh tersebut dahulu diucapkan dengan bahasa Jawa ngoko Wis digawa wit lair ya, KTP wujude ya iki leh, meskipun dituturkan oleh anak kepada orang tuanya karena dahulu masyarakat Samin beranggapan semua orang itu kedudukannya sama, tidak ada yang lebih tinggi dan juga tidak ada yang lebih dihormati antara yang satu dengan yang lainnya. Dengan demikian, dalam data (1) tersebut telah terjadi pergeseran bahasa dari bahasa Jawa ragam ngoko menjadi bahasa Jawa ragam krama. Saat ini, masyarakat Samin sudah menyadari perlunya penghormatan kepada orang lain yang salah satunya diwujudkan dalam bahasa Jawa krama.

(2) P1 : Lha sida dha buwoh pa rak? [lha, sidO 


\author{
O buwOh pO ra?] \\ 'Jadi pergi menyumbang, tidak?' \\ P2 : Sida \\ [sidO] \\ 'Jadi' \\ P3 : Teng pundi? \\ [t $\mid \mathrm{G}$ pundi] \\ 'Di mana?' \\ P1 : Mantren kuwi leh, sebelah kidule \\ Pak Lurah \\ [MantrEn kuwi 1Eh, sebelah ki- \\ dule pa? lurah] \\ 'Mantren (Kemantren), sebelah \\ selatan Pak Lurah'
}

Data (2) merupakan tuturan yang dilakukan oleh sebuah keluarga dalam masyarakat Samin. Tuturan tersebut terjadi dalam situasi nonformal antara seorang ayah (P1), ibu (P2), dan anaknya (P3). Topik yang dibicarakan adalah rencana menghadiri acara pernikahan tetangga desa. P1 bertanya kepada P2 tentang kepastian rencana menghadiri acara pernikahan lha, sido dho buwoh pa ra?. Tuturan tersebut menggunakan bahasa Jawa ngoko. Tuturan ini sesuai dengan kebisaaan masyarakat Samin ketika berkomunikasi. P2 menjawab pertanyaan P1 juga menggunakan bahasa Jawa ngoko. Namun P3 yang ikut dalam pembicaraan merespons tuturan P1 dan P2 menggunakan bahasa Jawa ragam krama. Tuturan teng pundi? yang diucapkan oleh P3 ditujukan kepada P1 dan P2 menggunakan bahasa Jawa ragam krama. Hal ini dilakukan karena P3 menghormati P1 dan P2 sebagai orang tuanya. Penghormatan dengan menggunakan bahasa Jawa krama ini tidak dapat dilakukan oleh masyarakat Samin karena masyarakat Samin terbiasa menggunakan bahasa Jawa ngoko, meskipun seorang anak kepada orang tuanya.

Dengan demikian, sesuai dengan konteks pada data (2) telah terjadi pergeseran kode dalam bahasa Jawa, yakni dari bahasa Jawa ragam ngoko menjadi bahasa Jawa ragam krama. Pergeseran itu ditunjukkan oleh P3 yang menjawab tuturan
P1 dan P2, yakni tuturan Teng pundi?. Sesuai dengan kebisaaan yang dilakukan oleh masyarakat Samin dahulu, ketika mereka berkomunikasi dengan sesama masyarakat Samin atau orang luar pasti menggunakan bahasa Jawa ragam ngoko karena mereka beranggapan semua orang itu sama, tidak ada yang lebih tinggi ataupun yang lebih rendah, sehingga tuturan tersebut pasti diucapkan neng endi? Namun ternyata sesuai dengan perkembangan, masyarakat Samin sudah menggunakan bahasa Jawa ragam krama ketika berkomunikasi, meskipun mereka berkomunikasi dalam ranah keluarga. Mereka sudah menyadari bahwa bahasa Jawa krama sebagai salah satu bentuk penghormatan kepada mitra tuturnya.

Pergeseran kode bahasa Jawa dari bahasa Jawa ragam ngoko ke bahasa Jawa ragam krama juga ditunjukkan oleh data (3) berikut ini.

(3) P1 : Mak, ngopi boten? [ma? GOpi bOt $\mid n$ ?] 'Pak, mau minum kopi tidak?'

P2 : Sapa neng ndi, teh wae leh [sOpO nEG ndi, tEh wae lEh] 'Siapa, di mana, teh saja'

P3 : Wis, ngidul leh, wis, wis, ya budhal

[wIs, GidUl 1Eh, wIs, wIs, yO bual]

'Sudah, ke selatan saja, sudah, sudah, ayo pergi'

P1 : Lha diombe kepiye Mak, kene lho [lha diombe klpiye Ma?, kene lho]

'Lha diminum, sini lho Pak'

Data (3) merupakan tuturan yang dilakukan oleh sebuah keluarga dalam masyarakat Samin. Dengan demikian, tuturan ini terjadi dalam ranah keluarga. Tuturan (3) terjadi dalam situasi nonformal antara seorang ayah dengan kedua anaknya (perempuan dan laki-laki). P1 (anak perempuan) menawarkan minuman kopi kepada ayahnya Mak, ngopi boten? Tuturan tersebut diucapkan oleh seorang 
anak perempuan ditujukan kepada ayahnya (sapaan Mak digunakan untuk menyebut ayah dalam BJS). Dalam tuturan tersebut terlihat bahwa P1 ketika berbicara dengan P2 menggunakan bahasa Jawa ragam krama. Hal ini ditandai dengan penggunaan kata boten yang disertakan dalam kalimat Mak, ngopi. Anak perempuan tersebut bermaksud menghormati ayahnya. Meskipun tuturan tersebut tidak sepenuhnya menggunakan bahasa Jawa ragam krama, tetapi penggunaan kata boten menunjukkan ada kosa kata krama yang digunakan dalam kalimat tersebut. Meskipun demikian, dalam tuturan berikutnya P1 tetap menggunakan bahasa Jawa ragam ngoko ketika berbicara dengan P2. Tuturan lha diombe kepiye Mak, kene lho dituturkan oleh P1 dan ditujukan kepada P2.

P2 (ayah) menjawab pertanyaan P1 dengan menggunakan bahasa Jawa ragam ngoko, sedangkan P3 (anak laki-laki) yang ikut dalam pembicaraan tersebut juga menggunakan bahasa Jawa ragam ngoko. Hal ini sesuai dengan kebisaaan yang dilakukan oleh masyarakat Samin ketika berkomunikasi.

Tuturan (3) menunjukkan ada kosakata krama yang digunakan oleh P1 meskipun tuturan lainnya tetap menggunakan bahasa Jawa ragam ngoko. Namun, penggunaan bahasa Jawa krama tersebut mengindikasikan telah terjadi pergeseran kode bahasa dari bahasa Jawa ragam ngoko ke bahasa Jawa ragam krama. Hal ini dilakukan oleh P1 tentu dengan maksud untuk menghormati P2 yang merupakan ayah dari P1. Bentuk penghormatan seperti ini tidak bisaa dilakukan oleh masyarakat Samin karena mereka berpendapat bentuk penghormatan lebih ditunjukkan dengan perbuatan, tidak dengan bahasa karena meskipun mereka berbahasa Jawa krama tetapi kalau perbuatannya tidak menunjukkan rasa hormat, maka mereka sebenarnya sama saja dengan tidak menghormati.

\section{SIMPULAN}

Saat ini BJS juga sudah mengalami pergeseran. Pergeseran BJS yang dimaksud dalam penelitian ini adalah pergeseran penggunaan kode bahasa Jawa dari tingkat ngoko ke bahasa Jawa tingkat krama. Pada mulanya, masyarakat Samin selalu menggunakan bahasa Jawa ngoko. Namun kini dalam penggunaannya, bahasa Jawa ngoko sudah sangat terbatas penggunaannya. Saat ini, masyarakat Samin sudah mulai mengenal dan menggunakan bahasa Jawa krama dalam berbagai kesempatan tuturan, apalagi jika tuturan itu dilakukan dengan orang non-Samin. Bahkan tuturan yang dilakukan antarsesama masyarakat Samin pun sekarang sudah menggunakan bahasa Jawa krama. Hal ini dilakukan masyarakat Samin karena mereka bermaksud menghormati orang lain yang menjadi mitra tuturnya. Selain itu, fungsi bahasa Jawa bagi masyarakat Samin juga sudah mengalami perubahan dari fungsi sebagai senjata untuk melawan penjajah menjadi alat komunikasi, baik dengan sesama masyarakat Samin maupun dengan masyarakat non-Samin.

\section{UCAPAN TERIMA KASIH}

Artikel ini merupakan bagian dari disertasi penulis pada Program Studi Ilmu-Ilmu Humaniora, Fakultas Ilmu Budaya, Universitas Gadjah Mada. Pada kesempatan ini, penulis mengucapkan terima kasih, khususnya kepada para pembimbing, yakni Prof. Dr. I Dewa Putu Wijana, S.U., M.A. (Pembimbing Utama) dan Prof. Dr. Soepomo Poedjosoedarmo (Pembimbing Pendamping) yang telah meluangkan waktunya untuk membimbing penulis. Ucapan terima kasih penulis sampaikan juga kepada Prof. Dr. Endang Nurhayati, M.Hum. dan Prof. Dr. Suwarna, M.Pd. yang telah berkenan menelaah artikel ini.

\section{DAFTAR PUSTAKA}

Errington, J. Joseph. 1998. Shifting languages: Interaction and Identity in Java- 
nese Indonesia. New York: Cambridge University Press.

Fasold, Ralph.1984. The Sociolinguistics of Society. England: Basil Blackwell Publisher.

Grimes, B.F (ed.). 2000. Ethnologue of The Word. Texas: Summer Institute of Linguistics, Inc.

Holmes, Janet. 1992. An Introduction to Sociolinguistics. New York: Longman.

Hudson, R.A. 1996. Sociolinguistics (Second Edition). Cambridge: Cambridge University Press.

Hutomo, Saripan Sadi. 1996. Tradisi dari Blora. Semarang: Citra Almamater.

Ibrahim, Gufran Ali. 2011. “Bahasa Terancam Punah: Fakta, Sebab-Musabab, gejala, dan Strategi Perawatannya" dalam Linguistik Indonesia Tahun ke-29, Nomor 1, Februari 2011, hal. 35 - 52.

Kartomihardjo, Soeseno. 1981. Etnography of Comminicative Codes in East Java. Disertasi. Pasific Linguistics, Series D, No. 39, The Australian National University, Canberra.

Mbete, Aron Meko. 2003. “Bahasa dan Budaya Lokal Minoritas, Asal-Muasal, Ancaman Kepunahan dan Ancangan Pemberdayaan dalam Kerangka Pola Ilmiah Pokok Kebudayaan Universitas Udayana". Pidato Pengukuhan Jabatan Guru Besar Tetap dalam Bidang Linguistik pada Fakultas Sastra Universitas Udayana, 25 Oktober 2003.

Miles, Matthew B dan A. Michael Huberman. 1984. Analisis Data Kualitatif. Terjemahan Tjetjep Rohendi Rohidi. 1992. Jakarta: Universitas Indonesia.

Muhadjir, Noeng. 1996. Metodologi Penelitian Kualitatif (Edisi III). Yogyakarta: Rakesarasin.
Mumfangati, Titi dkk. 2004. Kearifan Lokal di Lingkungan Masyarakat Samin, kabupaten Blora, Propinsi Jawa Tengah. Yogyakarta: Kementerian Kebudayaan dan Pariwisata.

Poedjoseodarmo, Soepomo. 1982. "Kode dan Alih Kode" dalam Jurnal Widyaparwa No. 22 Tahun 1982. Yogyakarta: Balai Penelitian Bahasa, halaman 1-43.

Rokhman, Fathur. 2009. Pergeseran Bahasa Indonesia di Era Global dan Imlpikasinya terhadap Pembelajaran. http://fathurrokhmancenter.wordpress.com (Diunduh tanggal 24 Agustus 2009).

Smith-Hefner, Nancy J. 2009. “Language Shift, Gender, and Ideologies of Modernity in Central Java, Indonesia" Journal of Linguistics and Anthropology, Vol 14, Issue 2, pp. 57 -77, ISSN 10551360. Boston : The American Anthropological Assosiation.

Sudaryanto. 1993. Metode dan Aneka Teknik Analisis Bahasa, Pengantar Penelitian Wahana Kebudayaan secara Linguistis. Yogyakarta: Duta Wacana University Press.

Sumarsono dan Paina Partana. 2002. Sosiolinguistik. Yogyakarta: Sabda.

Thomason, Sarah G. 2001. Language Contact, an Introduction. Edinburg: Edinburg University Press.

Wardhaugh, Ronald.1986. An Introduction to Sociolinguistics. Oxford: Basil Blackwell.

Widodo, Amrih. 1997. "Samin in the New Order: The Politics of Encounter and Isolation" dalam Imagining Indonesia: Cultural Politics and Political Culture. Jim Schiller dan Barbara MartinSchiller (Eds.). Ohio : Center for International Studies, Ohio University, hal. $261-187$. 